\title{
Dispositivity principle in the criminal procedure of Azerbaijan Republic: concept and application in individual rights
}

\author{
Gahraman V. Jafarov \\ Baku State University, \\ Baku, Azerbaijan Republic, \\ qehraman79@mail.ru
}

\begin{abstract}
Unlike other principles of criminal procedure (such as legality, presumption of innocence, etc.), the principle of dispositivity (the principle of autonomy of the will of a participant in the proceedings) does not have an independent legal formula, enshrined in a separate article in the current criminal procedure legislation of Azerbaijan. In this regard, questions about the existence, concept, content, individual elements, manifestations, and scope of the principle are becoming relevant and at the same time highly disputable. The author aims to determine the essence of dispositivity, to consider its individual manifestations, as well as to develop scientifically sound recommendations for optimizing the application in practice of the norms of the Code of Criminal Procedure in regulating issues related to the dispositive basis of the criminal process. The set goals predetermined solution for such basic issues as study of the philosophical and legal concept of dispositivity; determination of determinantsmanifestations of dispositivity in criminal proceedings as a whole; recognition of dispositivity as one of the autonomous principles of the modern criminal process of Azerbaijan. The study was conducted by methods of dialectical cognition based on the principles of reflection, comprehensiveness, unity of induction and deduction, determinism, contradiction, and unity of analysis and synthesis. The author has studied and summarized a great deal of doctrinal material and jurisprudence, and some selected judicial acts have been used as real models for casuistry of the issues addressed in the article. As a result of the study, the author substantiates that, despite the absence of an independent article in the CPC on this principle, dispositivity is an autonomous principle of criminal procedure, not covered by other principles; on the contrary, it enters into various correlative relations with them. In other words, the Code of Criminal Procedure does not provide a binding feature of the principle of criminal procedure. As the main determinants of the principle under study, the author proposes to consider a system of procedural rights of non-governmental participants in the proceedings that have the effect of initiating some kind of proceedings, and the "consent of a participant" category, which is a mandatory condition in the procedural decision-making mechanism of entities with power.
\end{abstract}

Key words: criminal procedure, dispositivity principle, freedom of will, rights, mutual relationship, law, theory, analysis

Conflicts of interest. The author declared no conflicts of interest.

Article received 28th October 2020

Article accepted 15th April 2021

(C) Jafarov G.V., 2021

This work is licensed under a Creative Commons Attribution 4.0 International License https://creativecommons.org/licenses/by/4.0 


\title{
For citation:
}

Jafarov, G.V. (2021) Dispositivity principle in the criminal procedure of Azerbaijan Republic: concept and application in individual rights. RUDN Journal of Law. 25 (2), 504-520. DOI: $10.22363 / 2313-2337-2021-25-2-504-520$

DOI: $10.22363 / 2313-2337-2021-25-2-504-520$

Научная статья

\section{Принцип диспозитивности в уголовном процессе Азербайджанской Республики: понятие и проявление в отдельных правах}

\author{
Г.В. Джафаров \\ Бакинский Государственный Университет, \\ 2. Баку, Республика Азербайджан, \\ qehraman79@mail.ru
}

\begin{abstract}
Аннотация. В отличие от иных принципов уголовного процесса (таких как законность, презумпция невиновности и т. д.), принцип диспозитивности (принцип автономии воли участника судопроизводства) не имеет самостоятельную юридическую формулу, закрепленную в отдельной статье в действующем уголовно-процессуальном законодательстве Азербайджана. В этой связи становятся актуальными и в то же время широко дискуссионными вопросы о наличии, понятии, содержании, отдельных элементах, проявлениях и пределах данного принципа. Автор преследовал цели определить сущность диспозитивности, рассмотреть отдельные ее проявления, а также разработать научно обоснованные рекомендации по оптимизации применения на практике норм УПК в части регламентации вопросов, касающихся диспозитивных основ осуществления уголовного процесса. Поставленные цели предопределили решение таких основных задач, как исследование философско-правовой концепции диспозитивности; определение детерминантов-проявлений диспозитивности в уголовного судопроизводстве в целом; аргументация признания диспозитивности в качестве одного из автономных принципов современного уголовного процесса Азербайджана. Исследование проведено методами диалектического познания, основанными на принципах отражения, всесторонности, единства индукции и дедукции, детерминизма, противоречия, единства анализа и синтеза. Автором был изучен и обобщен большой объем доктринального материала и судебной практики, а некоторые избранные судебные акты были использованы в качестве реальных моделей для казуистики рассматриваемых в статье вопросов. В результате исследования автором обосновывается вывод о том, что, несмотря на отсутствие в УПК самостоятельной статьи, посвященной этому принципу, диспозитивность является автономным принципом уголовного процесса, не охватывающимся иными принципами, наоборот, вступающим с ними в различные коррелятивные связи. Иными словами, закрепленность в УПК не рассматривается в качестве обязательного признака принципа уголовного процесса. В качестве основных детерминантов исследуемого принципа автор предлагает рассматривать: систему процессуальных прав невластных участников судопроизводства, имеющих эффект инициирования того или иного рода производства; категорию «согласие участника», выступающего в качестве обязательного условия в механизме принятия процессуальных решений субъектами, обладающими властными полномочиями.
\end{abstract}

Ключевые слова: уголовный процесс, принцип, диспозитивность, автономия воли, права, корреляция, закон, теория, анализ

Конфликт интересов: Автор заявляет об отсутствии конфликта интересов. 
Дата поступления в редакцию: 28 октября 2020 г.

Дата принятия к печати: 15 января 2021 г.

\section{Для цитирования:}

Jafarov G.V. Dispositivity principle in the criminal procedure of Azerbaijan Republic: concept and application in individual rights // RUDN Journal of Law. 2021. T. 25. № 2 . C. $504-520$. DOI: $10.22363 / 2313-2337-2021-25-2-504-520$

\section{Introduction}

Each of the principles of the criminal process envisages a legal formula of an idea, and this legal formula becomes more precise when it is defined in the existing law and can be expressed with a laconic name and sometimes even a word. However, there are principles in the criminal procedure law that openly debate about how they should be called and what provisions should be included in the legal formula, since the existing criminal procedure legislation does not provide for independent articles defining these principles. The principle of dispositivity in the criminal procedure is one of these principles. The decision of the Plenum of the Constitutional Court of the Republic of Azerbaijan On Interpretation of Articles 37.4, 39.1.9, 40.2 and 41.7 of the Code of Criminal Procedure of the Republic of Azerbaijan dated July 15, 2011 states: "unlike the special charge cases, the principle of dispositivity on crimes that do not pose a major public danger does not affect the starting stage of criminal proceedings. Article 73 of the Criminal Code does not specify the imperative norm. According to this article, the effect of dispositivity cannot be compared with publicity". Looking carefully at this section taken from the decision of the Constitutional Court, it becomes clear that the Constitutional Court in its decision refers to the principle of dispositivity and principle of publicity in the criminal proceedings. However, when we look at Chapter II of the Criminal Procedure Code (hereinafter referred to as the CPC) titled Tasks, Basic Principles and Conditions of Criminal Procedure, which was adopted on 14 July 2000 and came into force on 1 September 2000, we see that these principles are not defined as independent norms. Nevertheless, the existence of a dispositivity requirement in the criminal procedure of the Republic of Azerbaijan in the form of a legal principle has been confirmed in the Constitutional Court's Decision of July 15, 2011 On the Interpretation of Articles 37.4, 39.1.9, 40.2 and 41.7 of the CPC.

\section{Concept of dispositivity}

The principle of dispositivity reflects the idea of free will in exercising subjective rights. However, legal literature rightly states that not all rights of participants in criminal law relations can be regarded as dispositive rights. To be considered a dispositive law, they must meet certain criteria. First, a correspondent duty of the state official relevant to the dispositive right of the participants of criminal procedure legal relations should be included (for example, if a subject has the right to file a complaint, a public official should have the duty to review and resolve the complaint). Secondly, dispositive rights should always be directed to the protection of personal interests, and therefore, the powers of a criminal process participant stemming from public duty may 
not be considered dispositive rights. In this sense, criminal prosecution officials do not possess dispositive rights, although they have discretionary powers (procedural rights that they can use at their own discretion and on their own initiative). Finally, the use of (the exercise of) the right for the dispositional nature of the law should serve as the basis for the initiation, continuation or completion of a criminal process, any stage or form of proceedings (Dikarev, 2008:75—76; Shtol, 2009; Solomina, 2013:362 — 363).

It should be noted that the principles of criminal proceedings operate in close interrelationship, not in isolation from one another. This, in turn, creates a system of principles of criminal justice practice. This system, along with general characteristics common to all systems, has a number of features. This is because the principles of criminal proceedings have a special place and role among other criminal procedural norms. The system of criminal justice principles covers a single set of normative features with a high standard of legal power characterized by independence and stability; it is interconnected with systemic elements and other legal systems to better regulate issues arising during the initiation, preliminary investigation, trial, and resolution of criminal cases. Although they are combined into a system with a specific internal structure, the principles of criminal procedure retain the specific content of each of them. Instructions contained in the content of a particular principle, in addition to personalizing it, require that each principle be equally legal. The system of criminal procedure principles is organized in accordance with the purpose of execution of criminal proceedings. The purpose of execution of criminal proceedings is broader than the concept of principles of the criminal justice system and includes the latter. Therefore, statutory guidelines incorporated in the contents of the principles can only find their positive settlement when they are consistent with the purpose of criminal proceedings (Abbasova, 2015:86).

\section{Procedural rights manifesting dispositivity}

In order to fully understand the essence of the principle of dispositivity, it is necessary to touch upon the individual manifestations of this legal idea after paying close attention to the issue of its correlation with other principles of criminal proceedings. We consider it appropriate to include the following legal institutions as the main manifestations of the principle of dispositivity in criminal proceedings.

\section{The right to file a complaint (appeal) with the law enforcement agencies}

The commencement of criminal prosecution for some crimes in the criminal process of the Republic of Azerbaijan is directly related to the expression of will of the victim and whether he or she will file a complaint with the law enforcement agencies. In other words, the settlement of the issue of whether a criminal proceeding will commence depends on whether a person who has suffered directly from a crime will use the right to file a complaint (appeal) with law enforcement agencies about the crime committed or prepared in regard of them. From the provisions of Article 39.1.8 of the $\mathrm{CPC}$, it can be concluded that a criminal prosecution cannot be instituted in the absence of the victim's complaint and in the cases of special public accusation without the 
prosecutor's initiation of the criminal prosecution; if proceedings on the criminal case are commenced in such circumstances, they should be terminated. The right of the victim of a crime to file a complaint (appeal) is ensured by the duty of the competent authorities to prosecute. The scope of actions that require the victim's complaint (except for the cases provided for in Article 37.5 of the CPC) is set by the law in the form of a closed list in a unified system in Article 37.3 of the CPC. In criminal procedural law, these actions are considered to be prosecuted in the form of special public accusations and their scope is determined by the legislative body, depending on priorities and directions of the state's anti-crime policy (Yuldoshev, 2013:368).

Since the adoption of the CPC to date, there have been several changes to this system in relation to decriminalization and criminalization of various actions. There is no specific algorithm, accurate criteria, or precise formulas for determining the scope of crimes to be prosecuted under a special public prosecution. This is more of a political issue (crime prevention policy is intended).

\section{The right to file a special accusation complaint at court}

The existence of special accusation cases in criminal proceedings of any state, that is, the possibility of criminal prosecution under a special charge, is one of the main arguments in the effectiveness of the principle of dispositivity in the criminal procedural law of that state. In other words, special accusation cases (special accusation type of criminal prosecution) are one of the main manifestations of the principle of dispositivity in criminal proceedings.

National legal literature asserts that the broader emphasis on the principle of dispositivity in the implementation of criminal prosecution is one of the major factors that contribute to the success of crime prevention policies, and that expanding the dispositional norms in the CPC can become a viable tool in combating crime.

According to Article 37.2 of the CPC, special criminal prosecution is solely based on the victim's complaint on the offenses referred to in articles 147, 148, 165.1 and 166.1 of the Criminal Code and is terminated if the victim reconciles with the accused before the court enters the deliberation room.

Only the victim, known as the special accuser in special prosecution cases, can be regarded as the main subject of the prosecution function. The reason for this is that public criminal prosecution is generally carried out in relation to criminal acts that disrupt not only the legal and legitimate interests of the victim, but also the interests of the society and the state. In terms of character and severity, the prosecution of those who committed such crimes, including proving of the charge, is a duty of the competent authorities, not the victim. Since the victim under the CPC is not recognized as a subsidiary prosecutor with the public prosecutor in the course of criminal prosecution, the conduct of the public prosecutor in relation to the prosecution does not depend on their will. Such situation also makes the victim's disagreement with the public prosecutor's refusal to prosecute during the trial insignificant and does not prevent the court from terminating the criminal prosecution. During the trial, the coincidence of positions of the public prosecutor and the private prosecutor over the refusal to defend the charge is only necessary for criminal cases under special public prosecution (Veliyev, 2018:88). 
The legal literature states that a criminal prosecution legislator that establishes the criminal prosecution under special charge allows the victim to appeal to the criminal justice body and settle by themselves the issue of defending themselves when their rights and legal interests are violated by the criminal actions (referred to in Articles $147,148,165.1$ and 166.1 of the Criminal Code - Author). Therefore, these cases are called special cases.

Determining the scope of criminal cases to be prosecuted under a special indictment depends directly on the priorities and key directions of the state's anti-crime policy, as well as the extent to which the state has taken over its law enforcement functions. Also, sometimes the doctrine can be found to contain approaches and arguments that special charge criminal prosecution should be extended further and sometimes that this type of criminal prosecution must be abolished. The main argument of the supporters of the first approach is that special prosecution cases alleviate the workload of law enforcement agencies that carry out pre-trial and liberate them from such bureaucratic practices as taking numerous procedural actions on cases of crimes of little public danger that do not affect or affect to a lesser extent the public interest, making procedural decisions, etc. Supporters of the second approach, as a rule, argue that the absence of pre-trial proceedings on special criminal cases reduces the effectiveness of the preparation of necessary materials for trial, and sometimes victims of crime fail to collect the necessary evidence, and thus, they are deprived of the opportunity to defend their rights and legal interests. Proponents of this approach consider it more advisable to conduct a simplified form of inquiry into special accusation cases (Dvoretskova, 2012:46; Golubov, 2016:29; Golubov, 2016:30; Lomakin \& Mondohonov, 2015:4; Strukova, 2011:14-15).

However, as we have mentioned, each state decides which actions can be prosecuted in the form of special accusation cases based on its own internal policies, the level of legal awareness of its citizens, the crime situation in the country, the level of legal awareness and so on.

\section{The right to appeal against the procedural actions (inactions) and decisions of the prosecuting authority}

The existing criminal procedural legislation gives the right to complain to the participants of the criminal process and to other persons involved in the criminal proceedings about the procedural actions (inactions) and decisions of the prosecuting authority, which, by its nature, can be considered a dispositive right, because the use of the right to complain is directly related to the subject's free will and in most cases, necessitates the implementation of necessary proceedings by the public authorities (such as the prosecutor's investigation, the court's judicial review, etc.). Thus, according to Article 122.1 of the CPC, procedural actions or decisions of the prosecuting authority may be appealed by the participants of the criminal proceedings as well as by other persons involved in the criminal procedure as provided by law.

For effective enforcement of the right to file a complaint, there is an institute of procedural oversight in the criminal process, as there is a need for officials to carry out action based on the complaint, to keep the complaint in motion. Procedural control is 
an integral element of the criminal justice process, a specific law enforcement mechanism within the criminal process. Internal procedural oversight, prosecutor oversight, and judicial review play an important role precisely during the implementation of criminal proceedings. Preliminary procedural investigation is understood as a type of criminal procedural activity related to investigation of criminal procedural activity, detection, analysis, and elimination of criminal procedural violations carried out by the chief (or deputy chief in the absence of chief) of the investigative unit (department, office), the prosecutor and the judge during the initial investigation. The contents of the procedural oversight are not limited by the criminal procedural activity, but also include the legal relationship between the chief (or deputy chief in the absence of chief) of the investigative unit (department, office), prosecutor and court with the investigator, interrogator and other persons involved in the criminal case (Ehmedov, 2011:11).

Nevertheless, we think that in the full meaning of the word, the right to complain about the actions and decisions of the criminal procedure authority manifests itself as a dispositive right during judicial oversight proceedings, as they are initiated on the part of the complainant, and this is one of the main symptoms of a dispositive nature of procedural law.

The institution of filing a complaint with the court with the function of judicial control, which is a part of the of judicial oversight institution, launches judicial control over the legality of actions and decisions of criminal prosecution authorities (operational search, investigations, prosecutions, prosecutors) when there is information about violations of rights and freedoms. In the course of judicial oversight, the court has mainly two functions. The first is to ensure the legitimacy of individual actions and decisions taken by authorized criminal prosecution authorities and officials, and the second is to protect the rights and freedoms of the participants in the criminal procedure (to exclude unjustified and unlawful restrictions, putting an end to rights violation and restoration of violated rights). The issue of human rights protection arises directly from the very essence of judicial (oversight) proceedings (Abbasova, 2018:12).

The essence of the institution of judicial oversight and the symptoms of the right to file a complaint through judicial oversight allow characterizing the latter as a dispositive right. We believe that the issue of which subjects have this right should also be clarified. At first glance, Article 449.2 of the CPC clearly answers this question. Thus, pursuant to Article 449.2 of the CPC, the following persons have the right to file complaints against the procedural actions or decisions of the prosecuting authority: 1) the accused (defendant) and their defence counsel; 2) the victim and their legal representative; 3 ) other persons whose rights and freedoms are violated as a result of decision-making or action.

However, the experience of application of criminal procedural legislation has shown that the expression other persons whose rights and freedoms are violated as a result of decision-making or actions provided for in Article 449.2.3 of the CPC is not clear enough. In fact, the Plenum of the Constitutional Court of the Republic of Azerbaijan needed to make two decisions at different times on the official interpretation of the meaning of this expression. We believe that this indicates that Article 449.2.3 of the $\mathrm{CPC}$ is really a complex norm for law enforcement practice. 
Thus, the Plenum of the Constitutional Court first interpreted Article 449.2.3 of the CPC in its Decision On Interpretation of Article 449.2.3 of the Criminal Procedure Code of the Republic of Azerbaijan on August 5, 2009. The Decision stated that there are vastly different approaches related to the use of the expression other persons in Article 449.2 .3 of the CPC. Due to the differing views among the legal practitioners, there is a need for an official interpretation of the expression other persons. The Constitutional Court further showed that the right to file a complaint is an integral part of the rights and obligations that constitute the legal status of a person and should not be restricted in any area of government activities, except as expressly provided for by law; it should be ensured for anyone who enters into relations with public authorities or their officials. The right to file a complaint during criminal proceedings, including pre-trial stages, is of particular importance. Thus, during investigations of criminal cases in the course of administering justice and the fight against crime, arbitrary decisions or illegal actions (inactions) taken in some cases by investigators, interrogators, prosecutors or judges may go beyond the limits of the necessity of lawful restriction of the rights and freedoms of persons involved in criminal proceedings. Ensuring the rights and legitimate interests of the participants of criminal proceedings is one of the most important tasks of inquiry and investigation bodies, prosecutor's office, and courts. It is not possible to administer true justice and effectively fight crime without paying due attention to the rights of individuals, especially of those involved in criminal proceedings. The decision of the Constitutional Court Plenum made on the above-mentioned date concluded that since provision 449.2.3 of the CPC stating that the other persons whose rights and freedoms are violated as a result of decision-making or actions pertains to other participants of criminal proceedings, it does not exclude the witness's right to file a complaint against the procedural actions or decisions of the investigative authority. However, other participants in criminal proceedings, including witnesses, have the right to appeal decisions and actions (inactions) of officials of the criminal prosecution body, provided that the actions and decisions taken affect their legal and legitimate interests, damage their constitutionally established rights and freedoms or complicate their access to justice (availability of justice) (Abdullayev, 2018:497-498).

The Constitutional Court Plenum interpreted Article 449.2.3 of the CPC for the second time in its Decision On the Interpretation of the Provision of "Other Persons" entitled to file a complaint of Article 449.2.3 of the Criminal Procedure Code of the Republic of Azerbaijan" adopted on March 12, 2015. The Decision states that protection and enforcement of the rights and lawful interests of everyone involved in criminal proceedings is the main line of justice policy pursued by a legal state in the course of judiciary proceedings and is the only way to exercise judicial power. Enhancement of the rights and legitimate interests of such persons is in full accordance with the interests of both the individual and society. Provision of other persons whose rights and freedoms are violated as a result of decision-making or action of Article 449.2.3 of the CPC does not exclude the right of persons, who are not parties or participants to the criminal proceedings but are involved in a criminal procedure or who perform criminal procedural rights or duties in any form, to complain of the decisions or actions in case of violation of their rights and freedoms established by the Constitution and laws of the Republic of Azerbaijan by procedural decisions or actions. 


\section{The right to file a civil lawsuit in criminal proceedings}

The civil lawsuit in the criminal process is, first and foremost, an institution that serves to reimburse the damage inflicted as a result of a criminal act. According to the provisions of Article 183 of the CPC, a civil lawsuit can be filed at any time from the beginning of the criminal investigation until instituting court proceedings. The basis for the right to file a civil lawsuit is inflicting material, moral or physical harm to a person as a result of a crime.

The fact that the right to file a civil lawsuit in a criminal proceeding is of dispositive nature requires that the criminal procedure authorities do not conduct any proceedings in respect of the claim until a formal civil suit is filed. However, a systematic review of the existing criminal procedural legislation shows that some CPC provisions still consider appropriate to take certain measures to secure a civil claim, which has not been filed yet (which may be filed in the future, or is likely to be filed in the future). The existence of such provisions in the CPC, and the fact that the principle of dispositivity in civil litigation is fully enforced, cause serious differences of opinion in practice. Thus, according to Article 185 of the CPC, during criminal proceedings, the investigator, interrogator, prosecutor, or court must take steps to secure a civil claim that has been filed or may be filed in the future by the petition of civil claimant or their representative or at their own initiative. Apparently, the expression civil lawsuit that may be filed in the future in the norm allows to conclude that, under the law, the primary investigating body should take steps to secure a future civil claim payment, such as arrest on the relevant property and so on, even if the relevant lawsuit claim has not yet been filed, but there are reasonable expectations for the filing of a civil claim in the future for compensation of damages inflicted as a result of a crime. In other words, the referred articles give the power to the primary investigating authority to seize property and take other measures to secure possible future civil claims, even if no civil lawsuit has been filed. It is interesting that the legal position supported by the Supreme Court of the Republic of Azerbaijan on this issue is quite different. According to their position, unless a civil case is filed, the criminal procedure authority should not take action to secure it. The defence of such a legal position on the matter is clearly seen in the decision on the case of S. Guliyev under Articles 134, 186.2.2 of the Criminal Code published in the Supreme Court's Bulletin. We consider it appropriate to refer to the relevant parts of that document.

According to the decision, S. Guliyev was convicted under Articles 134 and 186.2.2 of the Criminal Code by the first judgment court, and the verdict also showed that 2500 AZN must be seized and paid to the victim (N. Hajiyev).

According to the case, S. Guliyev first raised a quarrel to prevent gathering watermelons planted by his son A. Guliyev and then intentionally threatened to kill A. Guliyev with a shotgun next day he saw that the watermelons harvested by A. Guliyev are collected in the RAF car belonging to his son-in-law N. Hajiyev. He damaged the car with an axe and burned it with a flammable substance, thus causing Mr. Hajiyev extensive damage worth 2500 AZN and deliberately destroying another person's property. The verdict was contested by appeal. The Shirvan Court of Appeal reversed the sentence removing the requirement to withhold $2500 \mathrm{AZN}$ from S. Guliyev 
and refer to the victim $N$. Hajiyev and adding to lift the arrest imposed on part of the house worth 2500 AZN belonging to the accused S. Guliyev estimated in full in the amount of 11,598.00 AZN by decision of the Aghjabedi District Court. The Court of Appeal's argument was that by the decision of the investigator of the Agjabadi district police department, N. Hajiyev was recognized as the victim of the case, and that day a protocol was compiled for him explaining his rights under Article 87 of the CPC and he was interrogated as the victim. However, during the interrogation, N. Hajiyev did not comment on his wish to claim for damage, as well as his wish to file a civil suit; he did not file a claim to be recognized as a civil claimant and there was no decision on recognising the victim as a civil claimant in the case, though he indicated the damage inflicted to his property was $2500 \mathrm{AZN}$ worth. The Court declared that the petition, reasoned by S. Guliyev's deliberate evasion of compensating the pecuniary damage in the amount of 2500 manat caused by S. Guliyev's criminal actions against N. Hajiyev, severely violated the CPC's requirements, because the petition filed by the investigator was submitted in the absence of a civil suit.

The Court of Appeals, referring to Article 248.1.1 of the CPC, stated that the meaning of the law is that property may be arrested on the ground that a civil lawsuit is filed during criminal proceedings... if no civil lawsuit has been filed during the prosecution, no further action shall be taken to secure it.

When it comes to the right to file a civil lawsuit in criminal proceedings, it is important to remember that filing a civil lawsuit does not mean that the case will be resolved in a criminal proceeding. The issue is that the criminal procedural legislation gives the court the authority to decide on the merits of the civil lawsuit, that is, the authority to resolve the civil lawsuit, in addition to the authority to keep the civil lawsuit pending. Of course, pending a civil lawsuit filed in criminal proceedings in practice results in dissatisfaction of civil claimant (victim), but they have no other choice than to defend the lawsuit as per civil litigation if pending of the civil case has been administered on legal grounds. For example, in one of the cases we selected from the Supreme Court's practice, the victim indicated in his cassation appeal that the courts had not ruled properly, hence his civil lawsuit is kept as pending/under review. He pointed out that there was no reason to keep the civil case under review and that there were no relevant records in the court rulings. The victim provided evidence that, pursuant to section 187.1 of the CPC, a civil lawsuit should be considered together with the prosecution material in the court concerned. The Supreme Court's Criminal Board's response to the victim's argument was as follows: the issue of civil lawsuit pending consideration has been resolved by the courts in accordance with the law. According to Article 180.3 of the CPC, a civil lawsuit filed during criminal proceedings but retained without consideration by the court may be later filed in civil proceedings. According to Article 183.3 of the Code, a civil suit may be filed in criminal proceedings only in writing. The lawsuit application should specify who is filing a civil suit against who, on what grounds and in what amount, and also contain a request regarding the withhold of a specific amount or property to pay the damages. The findings of the courts on retaining the claim pending review are grounded, since the civil lawsuit claim presented to the court by the victim does not identify evidence confirming the amount of moral and material damage inflicted. The property rights of the victim were not 
violated because his right to collect evidence and file a civil claim again for compensation of the damage caused by the crime has been lawfully retained (Decision of the Criminal Board of the Supreme Court of the Republic of Azerbaijan on the case No. 1(102)-72/2012 dated 17 January 2012).

\section{The right to challenge court judgments (other final rulings)}

As already noted, the ability of a participant of the process to exercise their procedural rights provided by law at their own discretion and will is a manifestation of the principle of dispositivity in criminal law. The right to challenge the court judgments (other final rulings) is also a right of dispositive nature, according to the aforementioned criteria. Judgments (other final rulings) of first instance courts that have resolved essentially a criminal case or other criminal prosecution material in the Republic of Azerbaijan can be challenged by appeal, cassation, and additional cassation.

The national legal literature rightly states that freedom of appeal is one of the main features of appellate proceedings. For example, F. Abbasova shows that review of court decisions in the course of appellate proceedings is possible in the presence of an appeal or protest. The subjects of the right to appeal to the relevant appeal court and their scope of jurisdiction are governed by Articles 383.1 and 383.2 of the CPC. Each subject has the right to freely exercise their rights. Thus, the manner in which a complaint is filed (in part, in full, in conjunction with other participants in the criminal proceedings, or independently), and the indication of grounds (evidence) for it, depend solely on the subjects themselves (Abbasova F.M., 2019; Bayramova K., 2019:72-77).

Although we agree with this view, it seems essential to make some adjustments. Thus, in our view, when it comes to challenging court judgments, it is necessary to consider freedom of appeal not only as a feature of the court of appeal, but also as an element typical of cassation and additional cassation proceedings.

As it was stated in the decision of the Military Board of the Supreme Court of the Republic of Azerbaijan on January 16, 2014, case 1-1(102)-29/14 selected from practice, the court of appeals acts as a full-fledged court. It re-examines the case based on its merits and administers justice using its powers to uphold the final decision of the court of first instance, substitute it, or cancel it, instead making a new decision. The appeal procedure provides for a re-examination of the legality and validity of the first instance court's judgment (other ruling) that has not yet come into force. In this case, the investigated judicial act is fully or partially audited. Audit of the judicial act, which is the subject of the examination, is carried out based on the compliance with the facts of the case, requirements of the existing evidence and legal and procedural law. In other words, the court of appeals is a court instance, which applies the rules of the criminal legislation (the norms of both the General and Special parts of the Criminal Code), as well as the norms of the existing criminal procedural legislation (the procedural legal rules of the Criminal Procedural Code and other laws or regulations as required) and examines and determines the actual circumstances of the case. The Court of Appeal, as 
the court of first instance, is interested in the proper determination of the facts of the case and is responsible for it.

When using their dispositive right to appeal court judgments (other final rulings) in the manner of appeal proceedings, the parties to the proceedings should take into account that new requirements not provided during the court review by the court of first instance shall not be considered by the court of appeals, except as provided by law. Under the existing criminal procedural legislation, new evidence is presented to the court of appeals in only two cases:

- if the participants of the criminal process justify the failure to present new evidence to the court of first instance with a reason beyond their control,

- if the court of first instance declines the investigation of this new evidence without an objective reason (Article 397.3 of the CPC).

New evidence may not be investigated in the court of appeal in any other case (Cahangirova, 2019:105-108).

In other words, the procedural right provided by the law for appeals is dispositive by nature, though not unlimited. While a participant of a criminal process may decide whether to exercise this right by their own will, when exercising this right, their wishes and desires in determining the scope of issues that they may dispute are limited only to matters that are subject to inquiry in the court of first instance. From this we can also conclude that dispositivity of a right does not mean that it is unlimited.

However, a criminal procedure participant can exercise the right to appeal and obtain their desired results. The reason for this is that the appellate instance has broad powers, that is, the right to judge and make decisions when considering a case. Unlike the cassation instance, the court of appeals can aggravate the penalty imposed by the sanction within the indictment. According to the Decision of the Plenum of the Constitutional Court of the Republic of Azerbaijan On Interpretation of Articles 397.1 and 397.2 of the Criminal Procedure Code of the Republic of Azerbaijan dated May 12, 2009, the following issues should be considered during application of Articles 397.1 and 397.2 until legislature made the relevant changes in the CPC:

- the court of appellate instance shall check the observance by the court of first instance of the norms of criminal and criminal procedural legislation in any case, even if there are no relevant claims in the evidence of the appellate complaint or protest,

- if the circumstances and grounds set forth in Articles 403 and 405 of the CPC are determined after checking for compliance with the provisions of criminal and criminal procedural legislation, and if the appeal proceeding is conducted on the basis of appeal complaint filed by convicted or acquitted person or their counsel or appeal protest substantially filed by the public prosecutor in favour of any of those persons, the appellate court may amend or abolish the final decision of the court of first instance by improving the situation of the person concerned and passing a new decision; if the appellate proceeding is in essence appealed by the public prosecutor to the detriment of the convicted or acquitted, or the appeal of the special prosecutor, the court of appellate may reverse the final decision of the first instance court or abolish it and make a new decision thus aggravating the situation of the acquitted person, irrespective of the evidence of the appeal; however, the decision may only be made unanimously by 
all judges of the appellate court considering the case, unless specified in the evidence of the main appeal.

As mentioned earlier, the right to appeal court decisions and other final decisions by filing a cassation appeal is also dispositive.

As noted in the Decision of the Military Board of the Supreme Court of the Republic of Azerbaijan on the case dated 1-1(102)-35/13 dated April 18, 2013 selected from practice, unlike the courts of the first and appellate instances, the cassation instance court does not determine whether a fact has taken place and expresses its attitude only to the correct application of the provisions of criminal and criminal procedural law based on the cases established by those courts. The court of cassation does not have the authority to instruct the court of appeal on consideration of an appeal complaint or appeal protest with or without court investigation, as well as to decide on the same.

Therefore, if the parties to a process, who are entitled to file a cassation appeal, want to challenge the judgment or other final ruling in a cassation procedure, they must take into account that, they may use the right to challenge the misapplication of material and procedural legal principles only in cases established by the first instance and appellate courts. They are not in the position to challenge whether any facts have taken place by using the relevant authority mentioned.

Finally, it should be noted that the opportunity to challenge judicial decisions in the manner of additional cassation acts is a right of dispositive nature. Additional cassation proceedings are an exceptional phase of criminal proceedings aimed at reviewing decisions made by the court of cassation instance and judicial decisions and judgments examined during the cassation proceedings. This procedure is one of the means enforced by the Constitution to enable citizens to re-apply to court.

The person acquitted in the criminal proceedings of the Republic of Azerbaijan does not have the right to file an additional cassation appeal. Thus, when the CPC was first enacted, the right to file an additional cassation appeal was granted only to the convict, but in accordance with the legal position of the Constitutional Court of the Republic of Azerbaijan dated March 19, 2002, the right of the victim and civil plaintiff to file an additional cassation procedure and to participate in such proceedings arising from the requirements of Articles 25, 68 and 127 of the Constitution of Azerbaijan Republic was limited by Articles 87.6.14, 89.4.12 and 422.3 of the CPC. In view of this, the Constitutional Court has recommended to the Parliament (Milli Majlis - the official law-making body) of the Republic of Azerbaijan to make relevant amendments to the CPC in accordance with Part I of Article 94 of the Constitution.

A long time after this recommendation - on June 10, 2011, the scope of the subjects entitled to file additional cassation complaints under Article 422.3 of the CPC was expanded at the expense of the victim, civil claimant, and their representatives. On December 11, 2012, a civil defendant, and on November 29, 2016, a representative of the legal entity to whom criminal measures were applied, were also added to the list of these subjects. However, the acquitted person still did not belong to those who have the right to file additional cassation complaints, even after all the listed amendments. Therefore, the right of an acquitted person to file a complaint to the higher court at present can only be referred to in the context of the proceedings in the appellate and cassation instances (Bayramova, 2019:72-77). 


\section{Solution of legal issues in criminal justice proceedings with the consent of the process participants}

A systematic review of the criminal procedure rules reveals that several norms attach particular importance to the consent of the parties involved in criminal legal relations, including the parties to the criminal procedure with legal consequences. Because voluntary consent relates to the expression of free will, this legal phenomenon falls within the scope of the principle of dispositivity in criminal procedural law.

Where a criminal proceeding requires the consent of subjects without authority to carry out a particular procedural act or to make a procedural decision, it follows the legal significance of the expression of free will, that is, the autonomy of the will of subject, which is an integral part of the principle of dispositivity. In other words, under the existing legislation, in particular cases, the imposition of officials' behavioural capabilities on the will (consent) of subjects without authority may be considered as one of manifestations of the principle of dispositivity. Because, in all cases where the subject's mechanism has been set up in connection with the legal result-based consent established as a standard condition that must be strictly enforced by law, the subject gets the freedom to exercise their rights to agree or disagree with undertaking of a particular procedural act or a procedural decision, at their own discretion. Therefore, the cases related to the said mechanism can be unilaterally considered as an element of the principle of dispositivity of the criminal procedural law.

However, it should be emphasized that the procedures for obtaining consent of the subjects that are a public authority (official) in both the pre-trial proceedings (presiding over the initial proceedings) and in the court (i.e. the public prosecutor) are not covered in the principle of dispositivity, because these subjects are engaged in representation and protection of public interests, not personal; the procedures for their consent to a particular act or decision should be considered as a means of exercising procedural powers, especially procedural oversight powers, not as an expression of freedom of will of the subjects (Haydarov, 2016:151—157; Pushkarev, 2017:29—32).

\section{Conclusion}

The ability of a process participant to exercise their procedural rights granted to them by law at their own will and discretion is a manifestation of the principle of dispositivity in criminal law. The principle of dispositivity in criminal proceedings of the Republic of Azerbaijan is not defined in Chapter II titled Tasks, Basic Principles and Conditions of Criminal Procedure, but in the Decision of the Plenum of Constitutional Court dated 15 July 2011 titled On interpretation of Articles 37.4, 39.1.9, 40.2 and 41.7 of CPC. Occasionally, one may also encounter an indirect manifestation of the principle of dispositivity in criminal proceedings through incorporation of one element such as freedom of will of a subject of criminal proceedings characteristic of the principle of dispositivity into the legal formula of another principle (for ex., Article 17 of CPC titled Ensuring of the Right to Inviolability of Housing).

Special prosecution cases (a special type of criminal prosecution) are one of the main manifestations of the principle of disposition in criminal proceedings. Every state 
makes their own decision regarding admissibility of special criminal prosecution of commitments considering such factors as its own internal policies, the degree of legal literacy of its citizens, the crime situation in the country, the level of legal awareness, etc. Determining the scope of criminal cases to be prosecuted on a special charge depends directly on the extent to which the state performs its law enforcement functions. We support the approach that special charge cases reduce the workload of law enforcement agencies conducting pre-trial proceedings and free them from such bureaucratic practices as taking numerous procedural actions on cases that pose little public danger, do not affect, or have a lesser influence over interests of society.

The commencement of criminal prosecution for some crimes in the criminal process of the Republic of Azerbaijan is directly related to the expression of the will of the victim and whether they will file a complaint with the law enforcement agencies. In criminal procedural law, these actions are prosecuted in the manner of special public prosecution. There is no specific algorithm, clear criteria, or precise formulas for determining the scope of crimes to be prosecuted under a special public prosecution. That is more likely to follow a political purpose. It is no coincidence that since the adoption of the CPC, there have been many amendments to the Code so far, on decriminalization and criminalization of various acts.

The right to appeal (implies a complaint from the procedural actions (inactions) and decisions of the prosecuting authority) is directly related to the freedom of the will of subject, and in most cases stipulates the necessary proceedings by public authorities (review by prosecutors, judicial proceedings by the court, etc.). For this reason, the right to appeal should also be considered a dispositive right. In the full sense, the right to complain about the actions and decisions of the prosecuting authority manifests itself as a dispositive right in the course of judicial proceedings/review by the court, or as judicial proceedings at the initiative of the complainant.

The fact that the right to file a civil lawsuit in a criminal proceeding is dispositive by nature requires that the criminal procedure authorities do not conduct any proceedings in respect of the claim until a formal civil suit is filed.

In relation to the disputing of a judgment or other final ruling, the freedom of complaint, which is an element of the principle of dispositivity, should be considered not only as a feature of the court of appeal, but also as an element typical of cassation and additional cassation proceedings. The procedural right for filing an appeal intended in the law is dispositive, although not limited. While a participant of a criminal proceeding may decide to exercise this right by their own will, their wishes, and desires in determining the scope of issues that he or she may dispute when exercising that right are limited only to matters that have been subject to inquiry in the court of first instance. When wishing to dispute court judgments or other final rulings in a cassation appeal, participants, entitled to file a cassation appeal, must consider whether they can dispute the misapplication of material and procedural legal norms in cases established by the first instance and appellate courts by using the relevant rights. They are not in the position to dispute whether any fact has occurred by using the applicable rights mentioned.

Because voluntary consent relates to the expression of free will, this legal phenomenon falls within the scope of the principle of dispositivity in criminal procedural law. 


\section{References / Список литературы}

Abbasova, F.M. (2015) Criminal procedure. General part. Coursebook. Revised $2^{\text {nd }}$ edition. Baku, Zerdabi Publ. (in Azerbaijan).

Abbasova, F.M. (2018) Special operations in criminal procedure. Handbook. Baku, Ecoprint Publ. (in Azerbaijan).

Abbasova, F.M. (2019) Criminal procedure. Special part. Coursebook. Revised $3^{\text {rd }}$ edition. Baku, Hugug Yayin Evi Publ. (in Azerbaijan).

Abdullayev, F.S. (2018) The Legal Positions of the Constitutional Court of Azerbaijan. New edition. T. 1. Baku. (in Azerbaijan).

Adamaytis, M. (2003) The consent of the parties is not identical to the consent of one party. Russian Justitia. (2), 30-31. (in Russian).

Адамайтис M. Согласие сторон не тождественно согласию одной стороны // Российская юстиция. 2003. № 2. С. 30-31.

Bayramova, K. (2019) On the right of the acquitted person to appeal to higher courts. Ganun journal. 7 (297), 72-77. (in Azerbaijan).

Cahangirova, Ş. (2019) Issues of reconsideration of court verdicts and other final decisions in criminal proceedings. Forensic Examination, Criminology and Criminology Issues. (67), 105-108. (in Azerbaijan).

Golubov, I.I. (2016) To the question of the advantage of an inquiry over a private prosecution. Russian Judge. (5), 27-33. (in Russian).

Голубов И.И. К вопросу о преимуществе дознания над частным обвинением // Российский судья. 2016. № 5. С. 27-33.

Golubov, I.I. (2016) On the need to abolish the private prosecution. Magistrate judge. (5), 33-40. (in Russian).

Голубов И.И. О необходимости упразднения частного обвинения // Мировой судья. 2016. № 5. С. $33-40$.

Dvoretskova, D.A. (2012) Challenges in expanding the scope of private prosecution cases. Bulletin of the Russian Law Academy. (2), 44 - 48. (in Russian).

Двореикова Д.А. Проблемы расширения круга дел частного обвинения // Вестник Российской правовой академии. 2012. № 2. С. 44-48.

Dikarev, I.S. (2008) The principle of dispositivity in the criminal process of Russia. Journal of Russian Law. (6), 73-78. (in Russian).

Дикарев И.С. Принцип диспозитивности в уголовном процессе России // Журнал российского права. 2008. № 6. С. 73-78.

Ehmedov, V.E. (2011) Theoretical and Practical Issues of Procedural Control at Stage of Preliminary Investigation. Synopsis of the dissertation submitted for the degree of Doctor of Philosophy in Law. Azerbaijan, Baku. (in Azerbaijan).

Haydarov, A.A. (2016) On the concept of "onsent" in the criminal process of Russia. Journal of Russian Law. (10), 151-157. (in Russian).

Хайдаров A.A. О понятии «согласие» в уголовном процессе России // Журнал российского права. 2016. № 10. С. 151-157.

Jahangirova, S. (2019) Judgments of the court in criminal proceedings and issues of reconsideration of other final decisions. Contemporary Problems of Forensics, Criminalistics and Criminology. (67), 105-108. (in Azerbaijan).

Lomakin, V. \& Mondohonov, A. (2015) Criminal cases of private prosecution as a way to increase the detection of crimes. Zakonnost. (6), 3-6. (in Russian).

Ломакин В., Мондохонов А. Уголовные дела частного обвинения как способ повышения раскрываемости преступлений // Законность. 2015. № 6. С. 3-6.

Pushkarev, V.V. (2017) Theoretical and legal construct "consent": epistemology of legal fact in criminal proceedings. Philosophy of Law. 3 (82), 29-32. (in Russian). 
Пушкарев В.В. Теоретико-правовой конструкт «согласие»: гносеология юридического факта в уголовном процессе // Философия права. 2017. № 3 (82). С. 29 -32.

Solomina, N. (2013) Dispositivity in criminal proceedings: the concept and forms of its manifestation. Intersystem and intersectoral relations in the legal sphere. Materials of the VIII International Scientific and Practical Conference of Students and Postgraduates. Kazan, pp. 362-363. (in Russian).

Соломина Н. Диспозитивность в уголовном процессе: понятие и формы ее проявления // Межсистемные и межотраслевые связи в правовой сфере: Материалы VIII Международной научно-практической конференции студентов и аспирантов. Казань, 2013. C. $362-363$.

Strukova, V.V. (2011) Is it reasonable to expand the category of cases as private prosecution cases? Criminal proceeding. (1), 13-17. (in Russian).

Струкова В.В. Обоснованно ли расширение такой категории дел, как дела частного обвинения? // Уголовное судопроизводство. 2011. № 1. С. 13-17.

Shtol, D.S. (2009) Dispositivity and its individual manifestations in the criminal proceedings of the Russian Federation. Abstract of the diss... cand. legal of sciences. Chelyabinsk, South Ural State university. (in Russian).

Штоль Д.С. Диспозитивность и ее отдельные проявления в уголовном процессе Российской Федерации: автореф. дис. ... канд. юрид. наук. Челябинск, Юж.-Ур. гос. ун-т, 2009. 34 c.

Yuldoshev, R.R. (2013) Proceedings in cases of private and private-public prosecution require systematization. Relevant Issues of Criminal Investigation. Materials of the International Scientific and Practical Conference. Moscow, Buki Vedi Publ. pp. 365-370. (in Russian).

Юлдошев P.P. Производство по делам частного и частно-публичного обвинения требует систематизации // Актуальные проблемы расследования преступлений: Материалы Международной научно-практической конференции. М.: Буки Веди, 2013. Ч. 1. C. $365-370$.

Veliyev, X.R. (2018) A Victim in Criminal Proceedings. Baku, Herbi Neshriyyat Publ. (in Azerbaijan).

\section{About the author:}

Gahraman V. Jafarov - Doctor of Philosophy in Law, Associate Professor of the Department of Criminal Procedure, Baku State University; 23 Academic Zahid Khalilov str., Baku, AZ 1148, Azerbaijan Republic

e-mail: qehraman79@mail.ru

\section{Об авторе:}

Джафаров Гахраман Вагиф оглы - доктор философии по праву, доцент кафедры уголовного процесса, Бакинский Государственный Университет; AZ 1148, Республика Азербайджан, г. Баку, ул. академика Захида Халилова, д. 23

e-mail: qehraman79@mail.ru 